\title{
OBITUARY
}

\section{Arthur Ferguson MacCallan}

Few medical men can have enjoyed so rich and varied a career as A. F. MacCallan, whose death on March 31, 1955, will be regretted by a wide circle of friends and colleagues, and by the ophthalmic profession throughout the world.

MacCallan was born in 1873, the son of the Reverend J. Ferguson MacCallan, M.A., who had left Northern Ireland to settle in Nottinghamshire. He was educated at Charterhouse, Christ's College, Cambridge, where he secured the Darwin Prize, and St. Mary's Hospital, London, which he entered as a University Exhibitioner. He was for some years a keen soccer player, but his athletic career was cut short by a serious accident to his knee while at Cambridge. In 1899 he obtained the Cambridge M.B. and F.R.C.S. (England), and he proceeded M.D. in 1913.

Early in his career MacCallan decided to specialize in ophthalmology. As a student he had been taken to Moorfields by $\mathrm{Mr}$. Silcock, and shortly after qualification he was appointed house surgeon to that hospital, and later worked there as chief clinical assistant.

The scourge of eye disease in Egypt was an age-old problem, which had received particular recognition in Europe since the return of troops from the Napoleonic Wars. At the turn of the century Sir Ernest Cassel, who had been interested in the construction of the Nile dam at Asswan, was moved by the prevalence of blindness in Egypt to donate a sum to further the education of Egyptian medical men in ophthalmic diseases. As a first step it was decided to establish a mobile hospital, and to the charge of this MacCallan was appointed in July, 1903.

From this beginning he evolved, by prodigious work and the help of Government and private funds, a vast organization, ultimately comprising base ophthalmic hospitals in each of the capital towns of the fourteen Egyptian provinces, six travelling

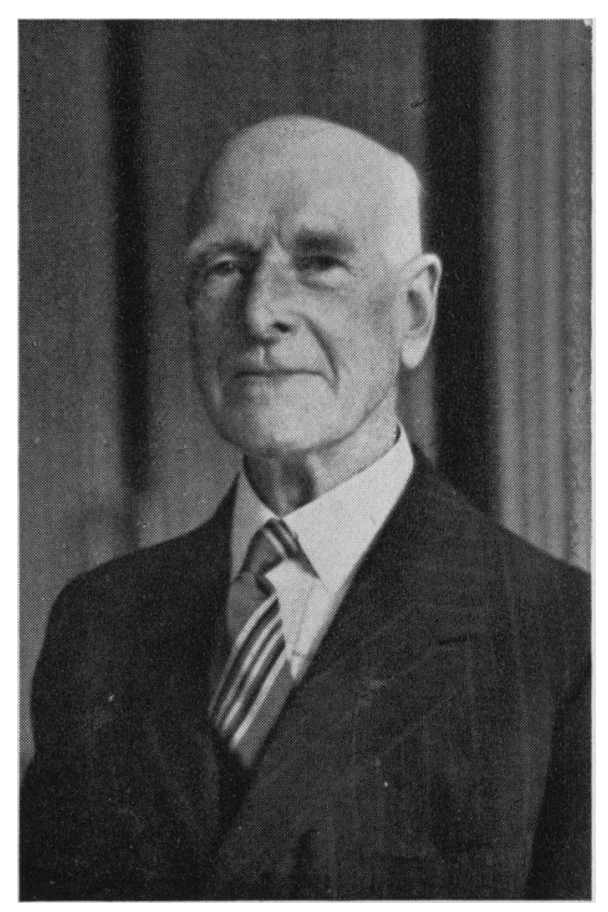

Arthur Ferguson MacCallan hospitals and numerous subsidiary clinics. The training of Egyptian ophthalmic surgeons received prior consideration, and regular courses of lectures and clinical instruction were provided. Research facilities were at first established in small centres, but these were superseded some years later by the magnificent Ophthalmic Laboratory at Giza, near Cairo, built as a memorial to the men of the Egyptian Camel Corps and Labour Corps, who had been killed in the war. No less important was the provision of ophthalmic treatment in all Government primary schools throughout Egypt, an innovation which was at first received with some hostility.

Lord Kitchener was particularly interested in these activities, and at his suggestion MacCallan undertook a programme of clinical research in ankylostomiasis and bilharziasis, for which four large tented hospitals were established. 
MacCallan was in England at the outbreak of the 1914 war, but at once returned to Egypt were he concentrated the travelling and tented hospitals at Alexandria as a general hospital for British and Australian sick and wounded. The static eye hospitals throughout the country were used for convalescent cases, though their out-patient departments were maintained as ophthalmic centres.

Later in the war MacCallan served as surgeon at a base hospital in Mersa Matruh, with the rank of Major, R.A.M.C. In 1920 he was made a C.B.E.

His work in Egypt provided MacCallan with unparalleled experience in the study of tropical diseases of the eye, and in particular of trachoma, on which he became a recognized world authority. In addition to many articles in the medical press, covering a wide field, he wrote a standard text-book on trachoma, and it was a fitting tribute to his work and to all that he had done to meet the ravages of this disease, that he was elected President of the International Trachoma Organization. From this position he only retired in September, 1954, after presiding over its activities during the XVII International Congress.

In 1923 MacCallan resigned from the service of the Egyptian Government. His great contributions to medicine in that country were recognized by two Egyptian decorations, and by the unique distinction of a bust of himself, presented by the ophthalmic surgeons of Egypt, which was unveiled by the High Commissioner in 1931.

Returning to England MacCallan proceeded to shape for himself a career as an ophthalmic surgeon in London. It was a striking tribute to his status, which he was proud to acknowledge, that in middle-age he was welcomed to the consulting staff of the Westminster Hospital and of the Royal Eye Hospital, to both of which, and to his private practice, he applied himself with customary zeal and enthusiasm. On reaching the age of retirement he continued research work at Westminster Hospital, and he resumed full clinical responsibility there during the war years.

MacCallan was a man of forceful character and incisive opinion, association with whom was always a stimulating and at times an exacting experience. Those of us who were privileged to work with him will remember him as a great clinician and teacher and as a pioneer and authority on the problems of trachoma. Some of us, too, will long cherish the memory of MacCallan as a host at his house in Welbeck Street, where his genial hospitality was abundant and his help and guidance freely given.

To Mrs. MacCallan, her daughter and two sons, deep sympathy will be extended from many quarters.

E. F. KING

\section{MARIANO SORIA}

WE regret to announce that Dr. Mariano Soria, Professor of Ophthalmology of the University of Barcelona and one of the best known ophthalmologists in Spain, died on March 30, 1955. Dr. Soria was president of the Jubilee Congress of the HispanoAmerican Congress in 1954.

\section{StePhen L. POLyaK}

Stephen L. Polyak, the greatest living authority on the anatomy of the visual system, died in Chicago on March 9, 1955, at the age of 65. He was born in Croatia and received his medical degree at the University of Zagreb. He was a health officer in the Serbian Army in the first world war. He taught neurology at the University of Zagreb from 1920 to 1928 , when he went to the United States. He was an assistant professor of neuroanatomy at the University of California, then went to the University of Chicago as an assistant professor of neurology in 1930. In 1938 he entered the antomy department and became Professor of Anatomy, when he began his research into the anatomy of the eye. His book on the retina is a classic, and before he died he had just finished a volume, "The Vertebrate Visual System ", to be published early in 1956. 